\title{
Uji Skrining Fitokimia Ekstrak Etanol Daun Ubi Jalar Ungu (Ipomoea Batatas L)
}

\author{
Agus Susanto $^{1}$ Hardani2 $^{*}$, Sri Rahmawati ${ }^{3}$ \\ ${ }^{1,2,3)}$ Program Studi Farmasi, Politeknik Medica Farma Husada Mataram \\ E-mail: 'agussoesanto69@gmail.com, ${ }^{2}$ danylastchild07@gmail.com, \\ ${ }^{3}$ rirahmawatifarmasi89@gmail.com
}

\begin{abstract}
ABSTRAK
Ubi jalar ungu merupakan tanaman yang sangat familiar bagi kita, dan yang paling umum adalah ubi jalar putih, ungu, kuning atau orange. Kelebihan dari ubi jalar ungu yang berwarna yaitu mengandung antosianin. Antosianin merupakan metabolit sekunder golongan flavonoid dan polifenol yang dapat berperan sebagai antioksidan. Konsentrasi antosianin inilah yang menyebabkan beberapa jenis ubi ungu mempunyai gradasi warna ungu yang berbeda. Antosianin memberikan efek kesehatan yang sangat baik yaitu sebagai antioksidan dan antikanker karena defisiensi elektron pada struktur kimianya sehingga bersifat reaktif menangkal radikal bebas. Daun ubi jalar selain dapat dimanfaatkan sebagai bahan makanan juga berpotensi sebagai obat untuk berbagai penyakit. Ubi jalar ungu (Ipomoea batatas L) merupakan salah satu komoditas pertanian di Indonesia yang memiliki jumlah produksi cukup melimpah serta dapat dijadikan sebagai bahan obat tradisional. Rumusan masalah dalam penelitian ini adalah apakah ekstrak Daun Ubi Jalar Ungu (Ipomoea batatas L.) mengandung senyawa kimia alkaloid, falovonoid, tanin dan saponin.Tujuan penelitian ini adalah untuk untuk mengetahui kandungan senyawa kimia dalam Daun Ubi jalar ungu (Ipomoea batatas L). Penelitian ini merupakan penelitian bersifat eksperimental yaitu dengan mengamati dan melakukan pengamatan eksperimental terhadap kelompok pada berbagai kondisi perlakuan. Sampel yang digunakan dalam penelitian ini adalah Daun Ubi jalar ungu (Ipomoea batatas L). Hasil penelitian ini menunjukkan bahwa daun Ubi jalar ungu tersebut positif mengandung senyawa kimia alkaloid, falovonoid, tanin dan saponin.Sehingga daun Ubi jalar ungu sangat refresentatif dijadikan produk herbal.
\end{abstract}

Kata kunci: Fitokimia, Ekstrak, Etanol, Daun ubi jalar ungu.

\begin{abstract}
Purple sweet potato is a very familiar plant for us, and the most common is white sweet potato, purple, yellow or orange. The advantages of colored purple sweet potatoes contain anthocyanins. Anthocyanins are a secondary metabolite of flavonoids and polyphenols that can act as antioxidants. This concentration of anthocyanins is what causes some kind of purple potato to have a gradient of different shades of purple. Anthocyanins provide excellent health effects namely as antioxidants and anticancer due to electron deficiency in its chemical structure so that it is reactive to resist free radicals. Sweet potato leaves can also be utilized as food ingredients as well as potentially medicines for various diseases. Purple sweet Potato (Ipomoea batatas L) is one of the agricultural commodities in Indonesia that has a number of production is quite abundant and can be used as a traditional medicine. The problem formulation in this study is whether purple sweet potato leaf extract (Ipomoea batatas L.) contains the chemical compounds of alkaloids, falovonoids, tannins and saponins. The purpose of this research is to know the content of chemical compounds in purple sweet potato leaf (Ipomoea batatas L). This research is an experimental study that is by observing and conducting experimental observations of the group in various treatment conditions. The sample used in this study is the purple sweet potato leaf (Ipomoea batatas L). The results of this study showed that the purple sweet potato leaves were positively contained.
\end{abstract}

Keywords: Phytochemicals, extracts, ethanol, purple sweet potato leaves.

*Korespondensi Author: Hardani, Politeknik Medica Farma Husada Mataram, E-mail : danylastchild07@gmail.com,Telp.081907456950

\section{PENDAHULUAN}

Tumbuhan memiliki peranan penting dalam kehidupan manusia, selain sebagai sumber bahan makanan, sandang, bahan bakar juga bahan-bahan industri ${ }^{1}$. Berbagai bahan kimia yang terdapat dalam tumbuhan juga dapat 
dimanfaatkan untuk obat-obatan, insektisida, dan kosmetika ${ }^{2}$. Bahan-bahan kimia tersebut bagi tumbuhan itu sendiri berfungsi sebagai media interaksi antara sesama tumbuhan maupun dengan makhluk hidup lain di sekitarnya serta untuk mempertahankan diri dari berbagai pengaruh luar ${ }^{1}$.

Pemanfaatan tanaman untuk kesehatan sudah dilakukan secara turun temurun oleh masyarakat. Kekayaan alam disekitar belum semuanya dapat diketahui, dimanfaatkan serta dikembangkan ${ }^{3}$. Masyarakat Indonesia telah lama menggunakan tanaman sebagai upaya untuk mengatasi masalah kesehatan. Pengetahuan terhadap khasiat suatu tanaman diketahui secara turun temurun dari generasi ke generasi. Pada saat ini, meskipun obat-obatan tradisional yang pengolahannya tradisional dan digunakan secara turun-temurun berdasarkan resep nenek moyang adat-istiadat, kepercayaan, atau kebiasaan setempat, diyakini memang bermanfaat bagi kesehatan dan kini digencarkan penggunaannya karena lebih mudah dijangkau masyarakat, baik harga maupun ketersediaannya ${ }^{4}$.

Obat tradisional pada saat ini banyak digunakan karena menurut beberapa penelitian tidak terlalu menyebabkan efek samping, karena masih bisa dicerna oleh tubuh ${ }^{4}$. Beberapa perusahaan mengolah obat-obatan tradisional yang dimodifikasi lebih lanjut. Bagian dari obat tradisional yang biasa dimanfaatkan adalah akar, rimpang, batang, buah, daun dan bunga. Salah satu tanaman yang digunakan untuk kesehatan adalah daun ubi jalar ungu ${ }^{3}$.

Ubi jalar Ungu (Ipomoea batatas L.) merupakan tanaman yang sudah terkenal di kalangan masyarakat karena dapat ditemukan di berbagai wilayah seluruh Indonesia. Ubi jalar ungu merupakan bahan pangan alternatif selain beras, yang merupakan sumber vitamin dan mineral yang sangat bermanfaat bagi kesehatan ${ }^{5}$. Bagian dari ubi jalar ungu yang banyak dimanfaatkan sebagai bahan pangan adalah umbinya, tetapi ternyata daun dari ubi jalar kandungan gizinya tidak kalah dengan umbinya sehingga sudah banyak digunakan sebagai sayuran oleh masyarakat. Ubi jalar ungu PUSLITBANG Sinergis Asa Professional, Jember merupakan tanaman yang sangat familiar bagi kita, dan yang paling umum adalah ubi jalar putih, ungu, kuning atau orange. Kelebihan dari ubi jalar ungu yang berwarna yaitu mengandung antosianin $^{6}$. Antosianin merupakan metabolit sekunder golongan flavonoid dan polifenol yang dapat berperan sebagai antioksidan ${ }^{5}$. Daun ubi jalar selain dapat dimanfaatkan sebagai bahan makanan juga berpotensi sebagai obat untuk berbagai penyakit.

Ubi jalar mengandung betakaroten (bahan pembentuk vitamin A) yang cukup tinggi. Semakin pekat warna ungu pada ubi, maka akan semakin tinggi kandungan betakarotennya7. Kandungan kimia pada ubi jalar lainnya adalah protein, lemak, karbohidrat, kalori, serat, abu, kalsium, fosfor, zat besi, karoten, vitamin B1, B2, C, dan asam nikotinat serta kaya akan polifenol.

Komposisi ubi jalar sangat tergantung pada varietas dan tingkat kematangan serta lama penyimpanan. Karbohidrat dalam ubi jalar terdiri dari monosakarida, oligosakarida, dan polisakarida. Ubi jalar mengandung sekitar 1640\% bahan kering dan sekitar $70-90 \%$ dari bahan kering ini adalah karbohidrat yang terdiri dari pati, gula, selulosa, hemiselulosa, dan pectin $^{8}$. Daun ubi jalar ungu mengandung komponen metabolit sekunder golongan flavonoid dan tannin serta memiliki efektivitas antioksidan yang relatif lebih tinggi berbanding dengan alfa tokoferol yang merupakan senyawa popular antioksidan 9 .

Daun ini mengandung saponin, flavonoid, dan polifenol. Umbinya mengandung karbohidrat dan baberapa vitamin ${ }^{10}$. Pengujian secara invitro menunjukkan bahwa daun ubi jalar ungu (Ipomoea batatas L.) yang muda mengandung kadar fenolik ${ }^{11}$. Bagian yang bisa dimanfaatkan adalah umbi dan daun. Daun ubi jalar ungu (Ipomoea batatas Var Ayamurasaki) secara empiris memiliki khasiat sebagai obat bisul, penurun panas, dan luka bakar ${ }^{10}$. Sedangkan untuk bagian umbi digunakan untuk mengatasi demam berdarah, asam urat, tekanan darah tinggi, masuk angin, kembung dan gangguan pencernaan ${ }^{12}$. 
Kandungan daun ubi jalar Ungu ini adalah mengandung saponin, flavonoid, dan polifenol ${ }^{13}$. Umbinya mengandung karbohidrat dan baberapa vitamin ${ }^{14}$.Ubi jalar (Ipomoea batatas L.) adalah tanaman yang mengandung senyawa aktif dalam bentuk flavonoid yang memiliki efektivitas antifungi ${ }^{15}$.

Ekstrak daun ubi jalar merah ternyata dapat menghambat untuk pertumbuhan bakteri Staphylococcus aureus penyebab bisul pada manusia ${ }^{16}$. Masyarakat di daerah pedesaan lebih cenderung memakai tanaman sebagai obat tradisional untuk menyembuhkan berbagai penyakit. Rumusan masalah dalam penelitian ini adalah apakah ekstrak Daun Ubi Jalar Ungu (Ipomoea batatas L.) mengandung senyawa kimia alkaloid, falovonoid, tanin dan saponin. Tujuan dari penelitian ini adalah untuk untuk mengetahui kandungan senyawa kimia dalam Daun Ubi jalar ungu (Ipomoea batatas L).

\section{METODOLOGI}

Metode penelitian yang digunakan dalam penelitian ini adalah metode Pra-eksperimen (Pra-Eksperimen Desain). Rancangan ini digunakan untuk mengungkap hubungan sebabakibat hanya dengan cara melibatkan satu kelompok subjek, sehingga tidak ada control yang ketat terhadap variable. Metode penelitian merupakan cara pemecahan masalah penelitian yang dilaksanakan secara terencana dan cermat dengan maksud mendapatkan fakta dan kesimpulan agar dapat memahami, menjelaskan, meramalkan dan mengendalikan keadaan ${ }^{17}$. Dari pengertian diatas peneliti menggunakan pendekatan penelitian kuantitatif dalam pelaksanaan penelitian ini.

Desain penelitian eksperimen semu berupaya mengungkap hubungan sebab akibat dengan cara melibatkan kelompok kontrol dan kelompok ekperimen tetapi pemilihan kedua kelompok tersebut tidak dilakukan secara acak ${ }^{17}$.

Jenis penelitian ini adalah jenis penelitian eksperimental yaitu dengan mengamati dan melakukan pengamatan eksperimental terhadap kelompok pada berbagai kondisi perlakuan. Sampel yang digunakan dalam penelitian ini adalah Daun Ubi jalar ungu (Ipomoea batatas L). Ekstrak etanol Daun Ubi jalar ungu (Ipomoea batatas L), merupakan ekstrak yang diperoleh dari penyarian Daun Ubi jalar ungu (Ipomoea batatas L) menggunakan pelarut etanol $70 \%$.

\section{HASIL DAN PEMBAHASAN}

Berdasarkan hasil penelitian, didapatkan hasil sebagai berikut:

Tabel 1. Data Uji Fitokimia daun Ubi jalar ungu (Ipomoea batatas $\mathrm{L}$ ).

\begin{tabular}{|c|c|c|c|c|c|}
\hline \multirow{2}{*}{$\begin{array}{l}\mathbf{N} \\
\mathbf{0}\end{array}$} & \multirow[t]{2}{*}{ Pengujian } & \multirow[t]{2}{*}{ Pereaksi } & \multirow{2}{*}{$\begin{array}{l}\text { Perubah } \\
\text { an yang } \\
\text { diamati }\end{array}$} & \multicolumn{2}{|c|}{ Hasil } \\
\hline & & & & $\begin{array}{c}\text { Positif } \\
(+)\end{array}$ & $\begin{array}{c}\text { Negati } \\
\mathbf{f} \\
(-)\end{array}$ \\
\hline 1 & Flavonoid & $\begin{array}{l}\text { Sampel + } \\
\mathrm{HCl}\end{array}$ & $\begin{array}{l}\text { Terbentu } \\
\text { knya } \\
\text { warna } \\
\text { hitam } \\
\text { kemerah } \\
\text { an }\end{array}$ & $\sqrt{ }$ & \\
\hline $\begin{array}{l}2 \\
.\end{array}$ & Tanin & $\begin{array}{l}\text { Sampel+ } \\
\text { FeCl31\% }\end{array}$ & $\begin{array}{l}\text { Terbentu } \\
\text { knya } \\
\text { warna } \\
\text { hijau }\end{array}$ & $\checkmark$ & \\
\hline 3 & Alkaloid & $\begin{array}{l}\text { Sampel+ } \\
\mathrm{HCl} 2 \\
\mathrm{~N}+ \\
\text { preaksi } \\
\text { mayer }\end{array}$ & $\begin{array}{l}\text { Terbentu } \\
\text { knya } \\
\text { endapan } \\
\text { putih } \\
\text { kekuning } \\
\text { an }\end{array}$ & $\checkmark$ & \\
\hline $\begin{array}{l}4 \\
.\end{array}$ & Saponin & $\begin{array}{l}\text { Sampel+ } \\
\text { Aquades }\end{array}$ & $\begin{array}{l}\text { Terbentu } \\
\text { knya } \\
\text { buih } \\
\text { yang } \\
\text { stabil }\end{array}$ & $\checkmark$ & \\
\hline
\end{tabular}

Keterangan :

$(+) \quad$ : Terjadi perubahan warna yang menandakan sampel mengandung senyawa kimia

( - ) : Tidak terjadi perubahan warna pada sampel.

Fitokimia bertujuan untuk menguji kandungan senyawa kimia yang ada dalam sampel ${ }^{15}$. Ekstrak kental etanol diuji fitokimia yang meliputi uji flavonoid, alkaloid, saponin dan tanin. Berdasarkan uji fitokimia yang telah dilakukan secara kualitatif terhadap ekstrak tanaman daun Ubi jalar ungu (Ipomoea batatas L), didapatkan hasil bahwa daun Ubi jalar ungu 
(Ipomoea batatas L) mengandung flavonoid, alkaloid, saponin dan tanin.

\section{Uji Flavonoid}

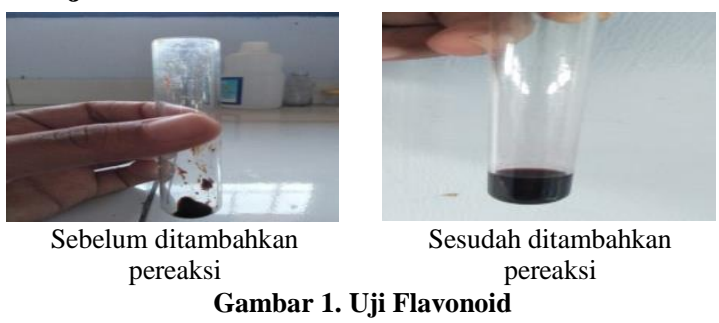

Hasil skirining fitokimia menunjukkan bahwa daun Ubi jalar ungu (Ipomoea batatas L) positif mengandung flavanoid, hal ini ditandai dengan terjadinya perubahan warna menjadi merah kehitaman setelah ekstak ditambahkan dengan $\mathrm{HCl}$ pekat. Warna merah kehitaman pada uji flavanoid dikarenakan terbentuknya garam flavilium $^{14}$.

\section{Uji Tanin}

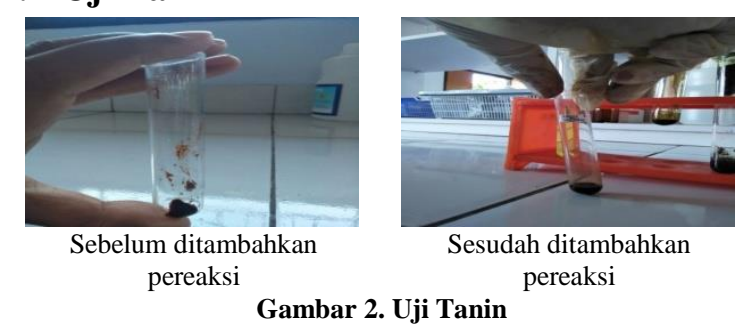

Hasil skirining fitokimia menunjukkan bahwa daun Ubi jalar ungu positif mengandung tanin, hal ini ditandai dengan terjadinya perubahan warna menjadi hijau pada saat penambahan larutan $\mathrm{FeCl}_{3}$ 1\%. Pada penambahan larutan $\mathrm{FeCl}_{3} \quad 1 \%$ diperkirakan larutan ini bereaksi dengan salah satu gugus hidroksil yang ada pada senyawa tanin. Pereaksi $\mathrm{FeCl}_{3} 1 \%$ dipergunakan secara luas untuk mengidentifikasi senyawa fenol termasuk $\operatorname{tanin}^{11}$.

\section{Uji Alkoloid}

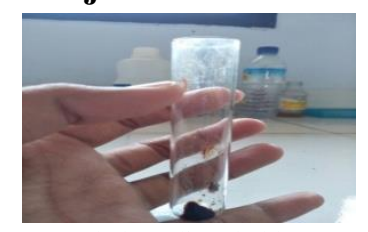

Sebelum ditambahkan pereaksi

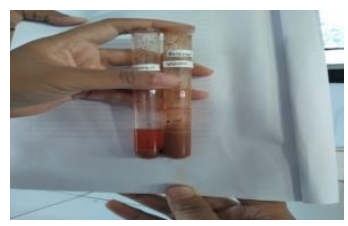

Sesudah ditambahkan pereaksi
Gambar 3. Uji Alkaloid

Berdasarkan hasil skrining fitokimia bahwa daun Ubi jalar ungu positif mengandung alkaloid, hal ini ditandai dengan terbentuknya endapan putih kekuningan setelah ekstrak ditambahkan dengan pereaksi mayer, diperkirakan nitrogen pada alkaloid akan bereaksi dengan ion logam $\mathrm{K}^{+}$dari kalium tetraiodomerkuat (II) membentuk kompleks kalium-alkaloid yang mengendap ${ }^{18}$.

\section{Uji Saponin}

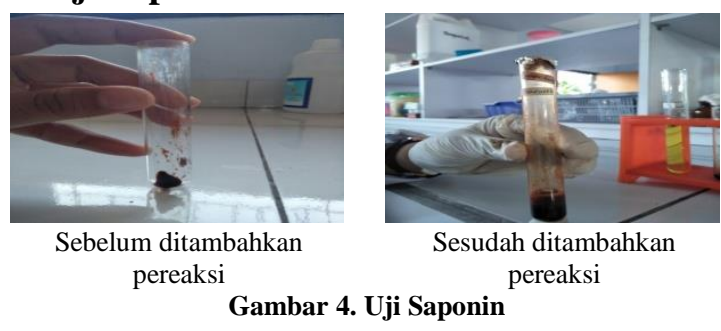

Berdasarkan hasil skirining fitokimia bahwa daun Ubi jalar ungu positif mengandung tanin yang ditandai dengan pembentukan busa/buih selama \pm 10 menit setelah ditambahkan aquadest. Senyawa yang memiliki gugus polar dan nonpolar bersifat aktif permukaan sehingga saat saponin dikocok dengan air dapat membentuk misel, gugus polar menghadap ke luar sedangkan gugus nonpolarnya menghadap ke dalam, keadaan inilah yang tanpak seperti busa ${ }^{12}$.

Alkaloid merupakan senyawa organik bahan alam yang terbesar jumlahnya baik dari segi jumlah maupun sebarannya. Alkaloid dapat didefinisikan sebagai kelompok senyawa yang bersifat basa (alkalis), karena mengandung atom nitrogen yang berasal dari tumbuhan maupun hewan ${ }^{19}$. Harbone dan Turner, 1984 dalam Trengginas, F, 2012, mengungkapkan bahwa tidak satupun definisi alkaloid yang memuaskan, tapi umumnya alkaloid adalah senyawa metabolid sekunder yang bersifat basa, yang mengandung satu atau lebih atom nitrogen dengan sepasang elektron bebasnya, dalam bentuk cincin heterosiklik dan bersifat aktif biologis menonjol.

Alkaloid tidak mempunyai nama yang sistematik, sehingga namanya dinyatakan dengan nama trival misalnya kodein, morfin, heroin, kinin, kofein, -nioktin. Dalam praktek medis kebanyakan alkaloid mempunyai nilai tersendiri, disebabkan oleh sifat farmakologi dan 
kegiatan fisiologinya yang menonjol sehingga dipergunakan luas dalam bidang pengobatan. Manfaat alkaloid dalam bidang kesehatan antara lain adalah untuk memacu system saraf, menaikkan atau menurunkan tekanan darah dan melawan infeksi mikrobia ${ }^{20}$. Suatu cara mengklasifikasikan alkaloid adalah cara yang didasarkan jenis cincin heterosiklik nitrogen yang merupakan bagian dari struktur molekul. Jenisnya yaitu pirolidin, piperidin, kuinolon,isokuinolin, indol, priding, dan sebagainya.

Flavonoid adalah suatu kelompok senyawa fenol yang terbanyak terdapat di alam. Senyawasenyawa ini bertanggung jawab terhadap zat warna merah, ungu, biru, dan sebagai zat warna kuning dalam tumbuhan ${ }^{21}$. Semua flavonoid menurut strukturnya merupakan turunan senyawa induk flavon", yakni nama sejenis flavonoid yang terbesar jumlahnya dan juga lazim ditemukan. Sebagian besar flavonoid yang terdapat pada tumbuhan terikat pada molekul gula sebagai glikosida dan dalam bentuk campuran, jarang sekali dijumpai dalam (berupa) senyawa tuggal ${ }^{21}$.

Disamping itu sering ditemukan campuran yang terdiri dari flavonoid yang berbeda kelas. Misalnya antosianin dalam mahkota bunga yang berwarna merah, hampir selalu disertai senyawa falvon atau flavonol yang tak berwarna. Flavonoid dalam tubuh manusia berfungsi sebagai antioksidan sehingga sangat baik untuk pencegahan kanker ${ }^{9,22}$. Manfaat flavonoid antara lain adalah untuk melindungi struktur sel, meningkatkan efektifitas vitamin $\mathrm{C}$, antiinflamasi, mencegah keropos tulang dan sebagai antibiotik ${ }^{9}$. Beberapa penelitian yang menjelaskan tentang senyawa flavonoid yang terdapat dalam kulit batang tumbuhan salah satunya adalah kulit batang Ziziphus mauritiana. Lam yang diekstrak mengandung beberapa senyawa metabolit sekunder antara lain flavonoid, alkaloid, saponin dan tanin.

Flavonoid merupakan senyawa penting yang berfungsi untuk mencegah kerusakan sel oksidatif yang bersifat sebagai antikanker dan melawan semua yang bersifat karsinogen ${ }^{22}$. Flavonoid juga dapat berfungsi untuk mengurangi resiko penyakit jantung. Selain senyawa flavonoid yang berpotensi sebagai antikanker, senyawa metabolit sekunder lainnya yang berpotensi adalah alkaloid. Alkaloid merupakan senyawa yang termasuk dalam metabolit sekunder yang bersifat basa yangmengandung satu atau lebih atom nitrogen $(\mathrm{N})^{22}$. Alkaloid seringkali bersifat beracun bagi manusia dan mempunyai fungsi fisiologis yang digunakan sebagai obat ${ }^{9}$.

Tanin merupakan senyawa tersebar luas dalam berbagai jenis tumbuhan, memiliki peran proteksi terhadap predator (sebagai pestisida) dan mengatur pertumbuhan suatu tumbuhan ${ }^{8}$. Tanin memilik berat molekul dari 500 hingga lebih dari 3.000 (misal ester dari asam galat) dan hingga 20.000 (biasa disebut proanthosianidin) ${ }^{8}$. Tanin memiliki beberapa kegunaan yaitu sebagai pelindung pada tumbuhan pada saat masa pertumbuhan, sebagai anti hama, sebagai pengawet dan penyamak kulit, reagensia di laboratorium untuk deteksi gelatin, protein dan alkaloid $^{8}$. Efek terapinya sebagai antiseptik pada jaringan luka, misalnya luka bakar, dengan cara mengendapkan protein.

Saponin merupakan senyawa glikosida kompleks, yaitu senyawa hasil kondensasi suatu gula dengan suatu senyawa hidroksil organik yang apabila dihidrolisis akan menghasilkan gula (glikon) dan non-gula (aglikon) serta busa $^{23}$. Timbulnya busa ilmiah yang menjadikan mudahnya indikasi adanya saponin ketika dilakukan uji skrining fitokimia. Saponin ini terdiri dari dua kelompok, yaitu: saponin triterpenoid dan dan saponin steroid. Saponin yang banyak digunakan dalam kehidupan manusia, salah satunya adalah untuk bahan pencuci kain (batik) dan sebagai shampo ${ }^{23}$. Saponin dapat di peroleh dari tumbuhan melalui metode ekstraksi dan isolasi. Saponin termasuk senyawa fitokimia yang dapat menghambat peningkatan kadar glukosa darah dengan cara menghambat penyerapan glukosa di usus halus dan menghambat pengosongan lambung ${ }^{23}$.

Dengan melambatnya pengosongan lambung, maka absorpsi makanan akan semakin lama dan kadar glukosa darah akan mengalami perbaikan ${ }^{23}$. 


\section{SIMPULAN DAN SARAN}

Berdasarkan hasil uji fitokimia terhadap daun Ubi jalar ungu tanaman tersebut positif mengandung senyawa kimia alkaloid, falovonoid, tanin dan saponin. Berdasarkan uji kualitatif fitokimia ekstrak daun Ubi jalar ungu perlu dilanjutkan penelitian secara kuantitatif kandungan fitokimia dari daun Ubi jalar ungu. Perlu adanya penelitian untuk mengembangkan khasiat dari daun Ubi jalar ungu dan dapat diproduksi menjadi sebuah sediaan obat tradisional dalam bentuk jamu, fitofarmaka dan obat herbal terstandar agar lebih mudah dikonsumsi oleh masyarakat luas.

\section{UCAPAN TERIMA KASIH}

Peneliti ingin mengucapkan terima kasih kepada Dosen pembimbing, laboran laboratorium Politeknik medica Farma Husada Mataram serta dukungan LPPM Politeknik Medica Farma Husada Mataram yang telah berkontribusi dalam penelitian ini.

\section{REFERENSI}

1. Aceh B, Pendahuluan I. ANTIFUNGAL ACTIVITY OF ESSENTIAL OILS SOME PLANTS IN ACEH PROVINCE AGAINST Candida albican. J Nat. 2012;12(2):18-22.

2. Primiani CN, Pujiati, Hardani. Estrogenicity of the isoflavone genistein pigeon pie seeds ( Cajanus cajan L. Mill sp.) on reproductive organs in rat. $J$ Phys Conf Ser. 2018;1025:012061. doi:10.1088/17426596/1025/1/012061

3. Darmaja H, Hardani I, Darmawan C, Supriyanto A. PEMBUATAN PROTOTIPE dye sensitized solar cells (DSSC) BERBASIS NANOPORI TiO 2 MEMANFAATKAN EKSTRAKSI ANTOSIANIN KOL MERAH (Brassica Oleracea Var).

4. Nisfiyanti Y. Sistem pengobatan tradisional. Sist Pengobatan Tradisional, Kasus, Stud Juntinyuat, Kec Indramayu, Kabupaten. 2012;4:129-140.

https://www.researchgate.net/publication/323 787130_SISTEM_PENGOBATAN_TRADI SIONAL_Studi_Kasus_di_Desa_Juntinyuat_ Kecamatan_Juntinyuat_Kabupaten_Indramay u/download.

5. Samber LN, Semangun H, Prasetyo B. Ubi Jalar Ungu Papua Sebagai Sumber Antioksidan. Semin Nas. 2012;18-188(Dewi 2007):3.samber.loretha@yahoo.com.
6. Dssc CA. Jurnal Fisika Flux Improved Performance of Dye-Sensitized Solar Cells With TiO 2. 2019;16(1).

7. Angraini LM. Indonesian Physical Review. 2019;2(3):106-115.

8. Setty Siamtuti W, Aftiarani R, Kusuma Wardhani Z, Alfianto N, Viki Hartoko I. Potensi Tannin Pada Ramuan Nginang Sebagai Insektisida Nabati Yang Ramah Lingkungan. Bioeksperimen $J$ Penelit Biol. 2017;3(2):83.

doi:10.23917/bioeksperimen.v3i2.5186

9. Adawiah A, Sukandar D, Muawanah A. Aktivitas Antioksidan dan Kandungan Komponen Bioaktif Sari Buah Namnam. $J$ Kim Val. 2015;1(November):130-136. doi:10.15408/jkv.v0i0.3155

10. Universitas Negeri Surabaya. Jurusan Ilmu Pengetahuan Alam A, Priyonggo FV. Jurnal penelitian pendidikan IPA. $J$ Penelit Pendidik IPA. 2018;2(2):38-44. https://journal.unesa.ac.id/index.php/jppipa/ar ticle/view/3089/1947.

11. Desinta T. Penentuan Jenis Tanin Secara Kualitatif Dan Penetapan Kadar Tanin dari Kulit Buah Rambutan (Nephelium Lappaceum L.) Secara Permanganometri. $J$ Ilm Mhs Univ Surabaya. 2015;4(1):1-10.

12. Qurrota A, Laily AN. Analisis Fitokimia Daun Pepaya ( Carica papaya L .) Di Balai Penelitian Tanaman Aneka Kacang dan Umbi , Kendalpayak, Malang The Phytochemical Analysis of Papaya Leaf ( Carica papaya L .) at The Research Center of Various Bean and Tuber Crops Kendalpayak. Fkip Uns. 2011:134-137.

13. Hardani, Cari, Supriyanto A. Efficiency of dye-sensitized solar cell (DSSC) improvement as a light party $\mathrm{TiO} 2$-nano particle with extract pigment mangosteen peel (Garcinia mangostana). AIP Conf Proc. 2018;2014:2-9. doi:10.1063/1.5054406

14. Setiabudi D., Tukiran. UJI SKRINING FITOKIMIA EKSTRAK METANOL KULIT BATANG TUMBUHAN KLAMPOK WATU ( Syzygium litorale ) PHYTOCHEMICAL SCREENING ON METHANOL EKSTRAK FROM STEAM BARK KLAMPOK WATU ( Syzygium litorale ) Dian Arista Setiabudi * and Tukiran Departement of Chemistry , F. UNESA $J$ Chem. 2017;6(3):155-160.

15. Agustina W, Handayani D. SKRINING FITOKIMIA DAN AKTIVITAS ANTIOKSIDAN BEBERAPA FRAKSI DARI KULIT BANTANG JARAK (Ricinus communis L.). Alotrop. 2017;1(2):117-122.

16. Darwis W, Melati P, Widiyati E, Supriati R. Efektivitas ekstrak daun ubi jalar merah (Ipomoea batatas Poir) terhadap bakteri 
Staphylococcus aureus penyebab penyakit bisul pada manusia. J Ilim Konserv Hayati. 2009;5(2):1-6.

http://repository.unib.ac.id/7860/1/Jurnal welly-putjha-eni Oktober 2009.pdf.

17. Iii BAB, Penelitian AM. Atikah Rahma Wulandari, $2014 \quad$ EFEKTIVITAS PERMAINAN TRIVIAL PURSUIT DALAM MENINGKATKAN PENGUASAAN KOSAKATA BAHASA JEPANG Universitas Pendidikan Indonesia | repository.upi.edu | perpustakaan.upi.edu. 2011;(2011).

18. 7134-9706-1-PB.

19. Shesy S, Iyos RN. Pengaruh Pemberian Ekstrak Daun Ungu (Graptophylum pictum Griff) terhadap Penyembuhan Hemoroid. $J$ Major. 2016;5(5):155-160.

20. Sutardi S. Kandungan Bahan Aktif Tanaman Pegagan dan Khasiatnya untuk Meningkatkan Sistem Imun Tubuh. J Penelit dan Pengemb Pertan. 2017;35(3):121. doi:10.21082/jp3.v35n3.2016.p121-130

21. Zarah J, No V. STRUKTUR, BIOAKTIVITAS DAN ANTIOKSIDAN FLAVONOID STRUCTURE BIOACTIVITY AND ANTIOXIDAN OF FLAVONOID. 2018;6(1):21-29.

22. Werdhasari A. Peran Antioksidan Bagi Kesehatan. Indones $J$ Biotechnol Med. 2014;3(2):59-68.

doi:10.22435/jbmi.v3i2.4203.59-68

23. Bintoro et al. ANALISIS DAN IDENTIFIKASI SENYAWA SAPONIN DARI DAUN BIDARA (Zhizipus mauritania L.). J ITEKIMA. 2017;2(1):84-94. 